\title{
The Human Resource Economics of Vernon Briggs
}

\section{Charles J. Whalen}

Utica College and Cornell University

E-mail: cjwhalen@cornell.edu

Paper last revised on June 12, 2009.

\section{Abstract}

This essay examines the conception of human resource economics (HRE) that shaped the career of Vernon M. Briggs $\mathrm{Jr}$. It probes the history of economic thought to describe the intellectual roots of HRE. It explores how HRE emerged to address the issues of economic growth, stabilization, and efficiency, as well as how it contributes to the public discourse on matters of social equity, economic opportunity, and government regulation. It explains the clash between human capital theory and HRE. And it outlines Briggs's five dimensions of human resource development (HRD), which is his term for HRE that manifests itself in public policy. Although Briggs developed his conceptualization decades ago, each dimension continues to warrant our attention.

Prepared for Human Resource Economics and Public Policy: Essays in Honor of Vernon $M$. Briggs Jr., Charles J. Whalen, editor (Kalamazoo, MI: W.E. Upjohn Institute for Employment Research, 2010). 
According to a Cornell University Web site, Vernon M. Briggs Jr. came to that university's School of Industrial and Labor Relations in 1978 "as a professor who specializes in human resource economics and public policy" (Cornell University 2009). In fact, Briggs's research and teaching helped establish that specialty, which I will simply refer to as human resource economics (HRE) in recognition of the fact that public policy is already inherent in Briggs's conception of those words. HRE resides at the intersection of the academic fields of economics, industrial relations, and public affairs.

This chapter traces and explores Briggs's conception of HRE. It probes the history of economic thought for the intellectual roots of this area of specialization. It examines how HRE emerged to address the issues of economic growth, stabilization, and efficiency, and to contribute to the public discourse on matters of social equity, economic opportunity, and government regulation. It explains the clash between human capital theory and HRE. And it outlines Briggs's five dimensions of human resource development (HRD), which is his term for HRE that manifests itself in public policy; although Briggs developed his conceptualization decades ago, each dimension continues to warrant our attention.

I base the chapter largely on a combination of Briggs's writings (especially Briggs 1987a,b, 1996), biographical interviews (Curington 2007; Rohe 2006), and my notes to his fall 1980 course, "Public Policy and the Development of Human Resources" (later renamed "Human Resource Economics and Public Policy”) (Briggs 1980) ${ }^{1}$ However, my essay is also colored by countless opportunities to read his works, listen to him lecture, or talk with him informally over nearly 30 years. 


\section{SMITH, MARX, AND COMMONS}

Briggs sees HRE as a policy-oriented field that considers human resources as a keyindeed, as the key— to economic progress and personal development. Adam Smith recognized that worker "skill, dexterity and judgment" is at the heart of the wealth of nations (Smith 1935, p

lvii). In fact, a labor theory of value is a cornerstone in the writings of classical economists from Smith to Karl Marx. Nevertheless, Briggs argues that HRE is a product of conditions found in post-World War II advanced industrial democracies.

Adam Smith's The Wealth of Nations came close to establishing HRE. According to Robert Heilbroner, "To see that labor, not nature, was the source of 'value' was one of Smith's greatest insights" (Heilbroner 1986, p. 49). Smith was even a pioneer in recognizing the harmful effects of routine work upon labor: "[T]he understandings of the greater part of men are necessarily formed by their ordinary employments. The man whose life is spent performing a few simple operations... generally becomes as stupid and ignorant as it is possible for a human creature to become" (Smith 1935, p. 734). Smith's solution? Public education, which would help counteract those effects (Smith 1935, pp. 734-738).

Yet Smith veered sharply away from Briggs's HRE by stressing the self-regulating nature of markets. Smith argued that self-interested individuals, engaging in market transactions, are led "by an invisible hand" to promote the interests of society as a whole (Smith 1935, p. 423). The result of that emphasis, intended or not, was an economic science that saw very little room for government intervention in economic life.

Marx also waded into territory that might have led to HRE, but taking a different turn than Smith, he concluded that "the proletarianization of the work force" would inevitably result in "a new socialist society" (Briggs 1987b, pp. 1208-1209). Briggs was not persuaded to follow 
Marx down that path. In the first chapter of the main textbook used in Briggs's fall 1980 course, "Public Policy and the Development of Human Resources," Garth L. Mangum writes, "Those who criticize American capitalism suggest no better alternative" (Mangum 1976, p. 27). Briggs might have been a bit more open than Mangum to learning from other advanced industrialized nations, especially those in Western Europe (Briggs 1987a, p. 8; 1987b), but he definitely shared Mangum's preference for capitalism over socialism.

Looking for a "third way" between Smith and Marx, Briggs saw a foundation for HRE in the institutional economics of John R. Commons. It is from Commons's "Wisconsin School" brand of institutionalism that Briggs's HRE gets its reformist bent. Rejecting centralized planning, institutionalism seeks "pragmatic ways to address the inevitable human adjustment problems associated with the advances of industrialization." The aim is practical problem solving, "designed to achieve a 'reasonable' and harmonious society" (Briggs 1987b, p. 1209).

Institutionalism is sometimes also called evolutionary economics. This is because institutionalists recognize that societal institutions are always in an "evolving" state. Thus, any economics based on an institutionalist foundation must aim to deal with changing circumstances in a dynamic setting (Briggs 2007). Moreover, evolutionary economists must accept that such changes place certain limitations on their work: Briggs approvingly quotes Edwin Witte - a student and colleague of Commons at the University of Wisconsin-who notes that, in dealing with public-policy questions, the institutionalists "seek not universal laws, but solutions applicable to a particular time, place and situation" (Briggs 1996, p. 373).

Although Commons provided HRE with an intellectual grounding, Briggs argues that economists did not begin to treat national public policies in this realm as a coherent and unified whole until the $1960 \mathrm{~s}$. In the opening paragraph to a 1987 article on HRD, Briggs writes, "One 
of the most insightful explanations for economic progress in industrialized nations during the last half of the twentieth century has been the recognition of 'human resources as the wealth of nations'" He continues: "The notion has long enjoyed rhetorical appeal by politicians in democratic societies. But awareness that the principle has enormous implications for national and international wellbeing has essentially been a post-World War II phenomenon." In particular, Briggs maintains it was only then that many economists and policymakers began to realize that HRD could play a central role in "efforts to address such difficult issues as efficiency, equity, stabilization, and growth" (Briggs 1987b, p. 1207).

\section{GROWTH, STABILIZATION, AND EFFICIENCY}

Briggs's reference to "human resources as the wealth of nations" comes from a 1973 Frederick H. Harbison book with that title (Harbison 1973). However, one can trace this literature back to the 1964 book by Harbison and Charles A. Myers, Education, Manpower, and Economic Growh ${ }^{2}$ Harbison and Myers examined 75 countries on the basis of a composite HRD index and compared those findings with national indicators of economic development and growth. Their main conclusion was that, to make the greatest strides in terms of growth and development, each nation needs to develop and implement a coherent HRD strategy that sets clear priorities and integrates them into an overall national economic-development agenda (one that recognizes and reflects broad social goals, not merely narrow economic objectives) (Harbison and Myers 1964).

Decades after publication of Education, Manpower, and Economic Growth, Briggs continued to stress the link between human resources and aggregate economic growth. Citing the work of both Edward Denison and Anthony Carnavale, Briggs demonstrated in 1987 that "while economists in general and public policymakers in particular have focused upon physical capital 
as the explanation for [productivity increases and] long-term growth, it has actually been human resource development that has been the major contributor... It is a fact of economic life that deserves prominence in policy formulation" (Briggs 1987b, pp. 1213-1214).

While economists' attention to the link between human resources and growth can be traced to the 1960 s, the place of human resources in economic stabilization took center stage in the 1970s. In 1971, Sar A. Levitan, Garth L. Mangum, and Ray Marshall produced a textbook entitled Human Resources and Labor Markets: Labor and Manpower in the American Economy. In one of its final chapters, the authors wrote, "Manpower expenditures and programs expanded continuously throughout the 1960 s, but were applied without any countercyclical intent." Still, they concluded that such human resource policies could constructively play a more active role in addressing economic fluctuations (Levitan, Mangum, and Marshall 1972, p. 517). ${ }^{3}$ In fact, another chapter in their book mentions the just-enacted Emergency Employment Act (EEA) of 1971, which did indeed seek to address the business cycle by offering temporary positions in periods of high unemployment (Levitan, Mangum, and Marshall 1972, p. 359). ${ }^{4}$

The nation's first experiment with countercyclical job creation since the Great Depression ran from 1971 to 1978 , first under the EEA and then under the Comprehensive Employment and Training Act (CETA) ${ }^{5}$ This direct job-creation initiative involved publicservice employment: local governments (and later also nonprofits) hired the unemployed to serve in any of a range of positions, including teachers' assistant, home-health aide, and police dispatcher, or to work on community conservation and weatherization projects. Studies by Briggs and others assessing this experiment concluded that "concerns about local governments substituting public-service employment for local funds were largely unfounded." They also found that the public-service employment programs "accomplished their desired fiscal effects," 
namely that they boosted aggregate spending and employment more quickly than tax cuts and that they directly targeted the unemployed (Marshall and Briggs 1989, pp. 598-601). President Ronald Reagan brought the public-service employment experiment to an end in 1981, but the experience of the 1970 s demonstrates that Levitan, Mangum, and Marshall had been right when suggesting that human resource policy could serve as an "important adjunct to monetary and fiscal policies" (Levitan, Mangum, and Marshall 1972, p. 517).

Although Briggs discussed the countercyclical aspects of public-service employment when I was his student in 1980 , I recall more vividly his suggestion that human resource policy can serve as an anti-inflationary device. Conventional fiscal policy addresses unemployment by increasing aggregate demand. From the vantage point of 1980 , however, there was considerable anxiety that employing such a strategy would exacerbate an already serious inflation problem. In other words, the fear was that more demand stimulus would simply yield a movement along the Phillips Curve (which depicts an inverse relationship between unemployment and inflation). At a time when a number of politicians and economists were actively promoting permanent tax cuts as "supply-side" economics, Briggs was offering a genuine supply-side solution: attacking joblessness in a way that reduces labor bottlenecks in the economy, thereby shifting the Phillips Curve in a manner that lowers the inflation rate associated with any given level of unemployment (Briggs 1980). ${ }^{6}$ In short, Briggs's HRE draws attention to training and labormarket services that have the potential to enhance both economic efficiency and stability in the face of rising prices.

In attempting to enlist labor-market policies in the fight against inflation, Briggs and other human resource economists underscored the distinction between cyclical, frictional, and structural unemployment. Cyclical unemployment—long explained with reference to a 
manufacturer who temporarily "lays off" employees during a recession and fully intends to rehire them when the slump abates-is the sort of joblessness that responds best to an aggregatedemand stimulus. ${ }^{7}$ Frictional unemployment, in contrast, is joblessness that signals a less than perfectly efficient labor market in the sense that, although appropriate work is available for job seekers, the unemployed and employers with vacancies have not yet located each other. To address this sort of unemployment and simultaneously combat price increases, human resource economists advocate not only better placement services, job-search counseling, and outreach programs that let workers know about employment opportunities, but also relocation assistance and other measures that enhance worker mobility (Levitan, Mangum, and Marhsall 1972, p. 515; Briggs 1980). Structural unemployment, meanwhile, involves a mismatch between the skills or characteristics of the jobless and the requirements of available positions; remedying this problem can also help attenuate inflation, but it often requires training and other interventions that reach beyond what is required to tackle frictional unemployment.

Labor economists were addressing frictional and cyclical unemployment long before the Great Depression (see, for example, Commons and Andrews 1916, pp. 261-290), but structural unemployment received considerably less attention until after World War II ${ }^{8}$ In the early 1960 s, though, the problem of structural unemployment was thrust into the national policy spotlight. Indeed, according to Briggs, this development is a major reason for the emergence of HRE as an academic area of specialization (Briggs 1980, 1987b, p. 1214-1218; Marshall and Briggs 1989, pp. $590-593){ }^{9}$

Careful observers of the early post-World War II economy noted that the average U.S. unemployment rate was rising with each successive period of cyclical prosperity. This "creeping prosperity unemployment" triggered a "full-scale debate among economists over whether 
structural changes in the economy had become more severe than in the past" (Marshall and Briggs 1989, p. 590 ). At the core of this debate was the concern expressed by a number of economists (most notably Briggs's professor at Michigan State University, Charles C.

Killingsworth) that automation, the emergence of computers, and associated technological change was eliminating the need for many unskilled workers and increasing the demand for skilled workers-such as "engineers, statisticians, programmers, mathematicians, and repairmen"-in "a broad array of industries" (Marshall and Briggs 1989, p. 591). If these economists were right, then stimulating aggregate demand would be an inefficient and perhaps even ineffective way of addressing the resulting unemployment. Thus, they argued, with some success, for "interventionist human resource policy ... especially for government-financed training, education, labor-mobility programs, and job-information systems that could focus on the groups who needed special assistance" (Marshall and Briggs 1989, p. 592). ${ }^{10}$

Soon after the notion of structural unemployment caught their attention, a group of labor economists-especially those most heavily influenced by the institutionalist tradition and its appreciation of incessant economic change — began to realize that "other structural changes were also transforming the labor force" (Marshall and Briggs 1989, p. 591). These changes included the shift from an economy heavily dependent on goods production to one more focused on services; a geographic movement of economic activity from the Northeast and Midwest and toward the South; an accelerated decline in agricultural employment; and the transition of baby boomers from school to work in the 1960s and 1970s. Still other changes appeared as well, along with a new term —-the "dislocated" worker (Marshall and Briggs 1989, pp. 591-593). Thus, HRE began as, and continues to be, an area that gives attention to structural economic change and its 
implications for the study of employment, and it couples that attention with a discussion of pragmatic policies that can foster more efficient and smoothly functioning markets. ${ }^{10 a}$

\section{EQUITY, OPPORTUNITY, AND REGULATION}

The civil rights movement is another major development contributing to the emergence of HRE and national human resource policy in the United States. Briggs addressed this in his 1980 course and in his textbook with Ray Marshall (Briggs 1980; Marshall and Briggs 1989, pp. 593-594). From those sources, it is clear that he views civil rights as a matter of human rights, social equity, individual economic opportunity, and national economic efficiency. For Briggs, ensuring equal opportunity means that government needs to tackle not only overt discrimination, but also institutional forms of discrimination, which range from procedural matters that affect hiring decisions to "the preparation of people for jobs" (Marshall and Briggs 1989, p. 593). He also sees this matter as moving HRE beyond Keynesianism's single-minded focus on the /eve/ of employment and toward the study of both the level and composition of employment (Marshall and Briggs 1989 , p. 594). ${ }^{11}$

Of course, Briggs has never been interested in equity and opportunity for racial and ethnic minorities alone; he has consistently been an advocate of equal opportunity for all. Thus, he was supportive of the "new" structuralist research of the 1970s. It demonstrated that minorities, women, and youth were entering the labor force in larger numbers and often faced employment challenges. Briggs stressed the fact that the "original" and "new" structuralist positions dovetailed. Looking at the matter from the macroeconomic viewpoint of the new structuralists, Marshall and Briggs emphasized that both structuralist variants are united in that they "stress the necessity of human-resource policies as the most equitable and efficient way to reduce aggregate unemployment rates" (Marshall and Briggs 1989, p. 592). 
The preceding quote indicates Briggs's HRE rejects the common assertion that equity and efficiency confront society in the form of an inescapable trade-off. Like Robert Kuttner, author of The Economic Illusion: False Choices Between Prosperity and Social Justice, Briggs has argued instead that this trade-off is often an "economic illusion" and that equity and efficiency are frequently "mutually reinforcing" (Kuttner 1984, p. 1). His essay "Efficiency and Equity as Goals for Contemporary U.S. Immigration Policy" provides just one of many examples of this, as even its title indicates (Briggs 1989).

Nevertheless, Briggs does not have a slavish devotion to markets. As an institutionalist, he rejects the mainstream economists' conventional assumption that economic efficiency is a "value neutral" concept. He also rejects their assertion that the neoclassical model of perfectly competitive markets is the only appropriate professional standard against which real-world markets should be judged.

Thus, Briggs's HRE is explicitly and unapologetically normative. In 1980, the final topic examined in his human resources course was "The Relationship of Research and Policy in the Human Resource Field," and one of the assigned readings was Objectivity in Social Research, by the institutionalist Gunnar Myrdal. The main point of Myrdal's slim volume is that there is no such thing as "objective" social research and that the closest a researcher can come to "objectivity" is to make value premises explicit-that is, to "expose the valuations to full light," and "make them conscious, specific, and explicit" in both theoretical and policy research (Myrdal 1969, pp. 55-56)..$^{12}$

The institutionalist way of thinking shapes Briggs's approach to the entire subject of labor-market regulation. Although Briggs has often called on the state to help labor markets operate more efficiently, he believes there are situations that require government to step in as a 
regulator, not merely as a facilitator. Policy views must be informed by theory but also by one's values-and (consistent with the institutionalist appreciation of a dynamic world) by an understanding of history.

This approach to regulation surfaced unmistakably in the mid 1980 s during the fortieth anniversary celebration at the Cornell University School of Industrial and Labor Relations (ILR). Participating in a panel devoted to examining the role of government in the workplace, Briggs began his remarks by reminding his audience why labor markets have become regulated: experience has shown that labor-market competition can often have serious adverse effects on workers. As a result, "[W]e now have a battery of worker protections sanctioned by laws and regulations. I think this is a very fundamental and justifiable outcome." In short, Briggs based his support for regulation on history and on a value judgment about what is the right way to operate an industrial society. "We don't want inadequate health and dangerous safety conditions, regardless of what any benefit-cost study might say... We cannot let exposure of workers to cancer-causing substances be determined by what happens in the marketplace. Period!" Briggs concluded: "As I see the world from my ivory tower, these interventions in labor marketswhich may end up distorting the perfectly competitive market model (the standard often used to evaluate deviations by these policy interventions) - serve to improve the imperfect world in which I live in and in which our workers work" (Briggs 1987a, p. 8). ${ }^{13}$

\section{HUMAN CAPITAL THEORY VERSUS HUMAN RESOURCE ECONOMICS}

HRE was not the economics profession's only post-World War II development that focused on the importance of human skills and knowledge. The other tradition, called human capital theory, emanated from the department of economics at the University of Chicago. Much of that work can be traced to the influence of Theodore W. Schultz, whose 1960 presidential 
address before the American Economic Association was entitled "Investment in Human Capital" (Schultz 1961)

A human resource economist in the Briggs tradition would probably quarrel with little in Schultz's address. His main point was to stress that investments in people are perhaps the most important of all determinants of economic growth, a point that served as the point of departure for the work of Harbison and Myers (1964) and many others. The address does contain a brief discussion of research by Gary Becker regarding on-the-job training, which suggests that Becker's reliance on a competitive-market model sets the stage for "meaningful economic studies" on that subject (Schultz 1961, p. 10). Still, Marshall and Briggs present Schultz's contributions without much critical commentary in their labor economics text (Marshall and Briggs 1989, pp. 24-25 and 213-214).

In contrast, Becker and other human capital theorists receive much more critical scrutiny from Marshall and Briggs (1989, pp. 177-192) and from Briggs on his own (1987b, pp. 12101213). Part of that critique relies on an essay by Michael J. Piore, which stresses that there is a huge gulf between the endeavors of human capital theorists and human resource economists. According to Piore, human capital theory is "applied theory concerned with the application of certain principles" derived from neoclassical economics (such as principles related to maximizing behavior and, as seen in the previous paragraph, the functioning of competitive markets). In contrast, HRE, rooted in institutional labor economics and informed by the manpower policy experience of the 1960s and 1970s, is "an applied field concerned with the solution of particular problems" (Piore 1974, p. 253).

Of course, Briggs's concern is not simply over the highly flawed nature of the assumptions of human capital theory. It is also that those assumptions lead to analyses that claim 
to be relevant to the real world. Building on a neoclassical foundation, human capital theory does not recognize "the significance of complex institutional practices and historical factors that influence labor-market operations," writes Briggs (1987b, p. 1211). He continues:

There is no allowance made for the ways that societal institutions (for example, schools, businesses, unions, government, or the military) can limit through their customs, practices, and policies the efforts of individuals to maximize opportunities to improve themselves. Nor is there any recognition of the historical barriers that have been placed in the paths of subgroups of the labor force to attain levels of human capital or to apply equally those human capital attributes that they do possess. Studies, for example, have found that many such workers often already have human capital endowments that exceed the limited range of jobs that are generally available to them. (Briggs 1987b, $\mathrm{p}$. 1211)

\section{DIMENSIONS OF HUMAN RESOURCE DEVELOPMENT}

Drawing on a 1987 essay by Briggs entitled "Human Resource Development and the Formulation of National Economic Policy," one can identify five HRD dimensions. The first three are national and economic in nature: workforce quantity, quality, and opportunity. The other two are personal development and international well-being.

\section{Workforce Quantity}

One way to look at the quantitative dimension of HRD is to begin with the number of employed people in the United States. In January 2009, the official number was just under 142.1 million. To be counted among the employed by the U.S. Bureau of Labor Statistics (BLS), a person must first be viewed as part of the civilian labor force. To be included in the labor force, one must be 16 years of age or older, reside in one of the 50 States or the District of Columbia, 
and not be confined to an institution (home for the aged, prison, or mental-health facility). There were 153.7 million people in the U.S. labor force in January 2009 (U.S. BLS 2009).

Of course, not everyone in the labor force is counted as employed, a category that requires a minimum number of hours worked within a certain BLS reference period. A member of the labor force can also be "unemployed," which requires one to be available and either searching for work or waiting to be recalled by an employer. There were 11.6 million unemployed people in the United States in January 2009, 7.6 percent of the labor force (U.S. BLS 2009).

The 7.6 percent unemployment rate of January 2009 is one measure of unutilized labor, but there are also potential workers who are part of the U.S. population and not currently part of the labor force. Many of those potential workers fall within a BLS category of people who are "marginally attached" to the labor force. These are "persons not in the labor force who want and are available for work, and who have looked for a job sometime in the prior 12 months (or since the end of their last job if they held one within the past 12 months), but were not counted as unemployed because they had not searched for work in the 4 weeks preceding the [most recent BLS employment] survey" (U.S. BLS 2008). There were about 2.1 million marginally attached workers in January 2009 , including 734,000 "discouraged workers," who were no longer looking because they believed no jobs were available to them (U.S. BLS 2009). ${ }^{14}$

There is also underutilized labor. For example, the BLS identified 7.8 million of the employed labor force as involuntary part-time workers in January 2009. These people would like to work full time but had their hours cut back or were unable to find full-time jobs (U.S. BLS 2009). Another category of underutilized labor is underemployment, which involves people working in positions that require less skill and education than they possess 
Looking over this terrain, Briggs has often called for a comprehensive national human resource strategy that would include a commitment to full employment. He envisions a strategy that would address not just the unemployment rate but also the challenges surrounding marginal attachment and underutilization. This strategy would have a macroeconomic component involving fiscal and monetary policies, but it would also include a battery of labor-market and education policies that recognize the need for remedies tailored to fit different circumstances. $\mathrm{He}$ writes: "Different groups in the labor force have different needs. Hence, a menu of policy options needs to be offered" (Briggs 1987b, pp. 1216-1217).

Immigration is also an important part of the quantitative dimension of HRD. In fact, its role has been growing for decades. In the 1980s and 1990s, immigration accounted for 37 and 47 percent of the growth in the U.S. population, respectively. In the first half of the twenty-first century, two-thirds of the nation's population growth "will be the consequence of the arrival of immigrants themselves and of their future children who will be born in this country" (Briggs 2003, p. 4). Quoting from a National Research Council report, Briggs writes in Mass Immigration and the National Interest, that immigration to the United States "will obviously play the dominant role in our future population growth" (Briggs 2003, p. 4).

According to Briggs, there are few nations in the world that accept significant numbers of immigrants each year, and the tendency among these nations is to adjust the numbers annually according to labor-market conditions. In contrast, immigration policy in the United States focuses heavily on family unification and "has been allowed to function independently of its economic consequences" (Briggs 1987b, p. 1221; 2003).

The United States is also the destination for many illegal immigrants. "An estimated 11.8 million unauthorized immigrants were living in the United States in January 2007 compared to 
8.5 million in 2000," according to a U.S. Department of Homeland Security report (Hoefer, Rytina, and Baker 2008, p. 1).

In his presidential address before the institutionalist Association for Evolutionary Economics, Briggs explained his concerns about the impact of immigration upon the U.S. economy:

The flow of immigrants into the United States has tended to be bimodal in terms of human capital attributes (as measured by educational attainment), but the highest concentration by far is in the lowest end of the nation's human capital distribution. ... In the low-skilled labor market, immigration has increased the competition for whatever jobs are available... As for skilled jobs, immigration can be useful in the short run as a means of providing qualified workers where shortages of qualified domestic workers exist. But, the long-term objective should be that these jobs should go to citizens and resident aliens. (Briggs 1996, p. 381) ${ }^{15}$

Thus, Briggs believes that immigration policy must be treated as an integral part of the nation's human resource strategy. During an interview in 2006, for example, he summarized his position as follows, "Immigration should primarily be linked to filling skill gaps in the labor force until the nation's own education and training system can meet those needs. The human capital of immigrants should not run counter to these needs" (quoted in Rohe 2006, p. 233). ${ }^{16}$

\section{Workforce Quality}

In addition to a quantitative dimension, HRD must also have a qualitative dimension. For Briggs, a nation interested in the qualitative dimension of human resources must address the needs of its most economically disadvantaged residents, but it must also do more, including 
engage in "preventive maintenance" and embrace the notion of "long-run educational development" (Briggs 1987b).

In the case of those who cannot find employment on a regular and self-supporting basis, or who must rely on the underground economy, Briggs stresses that society must "provide a lifeline of opportunity to prepare for legitimate employment" (Briggs 1987b, p. 1225, emphasis added). Doing so is both just and economically pragmatic, he argues. His 1987 essay on HRD illustrates this need with a discussion of three U.S. economic problems: the declining labor-force participation of black males, the poverty challenge facing female-headed households, and increasing adult illiteracy (Briggs 1987b, pp. 1225-1227).

The problems facing black males have not receded. A 2006 volume edited by Ronald B. Mincy for the Urban Institute finds the labor force participation rate for black men continued to decline even during the economic boom of the 1990s (Mincy 2006). A 2004 report by Andrew Sum and his colleagues at Northeastern University, meanwhile, finds a decline in the employment-to-population ratio of black men that began in the mid 1950 s and continues into the mid $2000 \mathrm{~s}$. It also finds a high and rising rate of year-round joblessness among black men (one out of every four were idle all year in 2002) (Sum et al. 2004b). Moreover, both of these recent studies advocate the sort of targeted education and workforce-development strategies that Briggs has been promoting for decades.

Poverty among female-headed households and the illiteracy problem also remain serious. Briggs's HRD essay indicated that "one out of every three families headed by a woman was living in poverty" in 1985 (Briggs $1987 \mathrm{~b}$, pp. 1225-1226). In mid 2005, the poverty rate for such families was 29 percent-10 times the rate found in two-parent families (Gosling 2008, pp. 175176). A 2002 report on an adult literacy survey, sponsored by the U.S. Department of Education, 
concluded that about 44 million of the 191 million adults in the United States have skills that place them in the lowest of five possible levels on prose, document, and quantitative proficiency. Many respondents "had such limited skills that they were unable to respond to much of the survey" (Kirsch et al. 2002, p. 18). The following year, another literacy program estimated that 50 million Americans cannot read or comprehend above the eighth-grade level and that nearly 75 percent of the unemployed are illiterate (Morry 2003).

Along with a lifeline for the unemployed and working poor, Briggs's national system of HRD would have a preventive maintenance component that offers assistance to anyone who becomes vulnerable to unemployment, regardless of salary history. In his 1987 essay on HRD, Briggs stressed the increasingly dynamic nature of the workforce in addition to the increased skill and educational requirements associated with the fast-emerging service-based economy. He also highlighted the inefficiency and impracticality of depending entirely on individuals to adjust to these changing employment patterns on their own. Thus, he called on government to develop a network of programs that would assist individuals with this readjustment process by providing reliable information on labor-market trends and job requirements and by offering workers ample opportunities for educational upgrading, job retraining, employment counseling, and even relocation when appropriate (Briggs 1987b, pp. 1227-1230).

Since education is the cornerstone of Briggs's strategy for achieving national success in a dynamic, global economy, long-run educational development is also essential to his conception of the qualitative dimension of HRD. In particular, he has often called for a major national effort toward five educational objectives: preventing students from dropping out of school; boosting the average literacy and educational proficiency level across American society; ensuring that education is contingent on ability to learn, not ability to pay; making educational opportunities 
accessible to adults throughout their working lives; and linking education reform to a national industrial policy. ${ }^{17}$ Briggs recognizes this will require extensive changes within U.S. educational institutions (affecting administrative practices, teacher certification and compensation, school decision-making, student assessment methods, and more), but he insists such changes are needed for education "to contribute to the answer and not worsen the problem of contemporary laborforce adjustment" (Briggs 1987b, pp. 1230-1231).

\section{Equal Employment Opportunity}

A workforce-opportunity dimension to $\mathrm{HRD}$ exists alongside the quantitative and qualitative dimensions. As with labor-market regulation in general (discussed earlier), Briggs addresses employment opportunity by beginning with the historical record. Whereas conventional economics argues that discrimination is irrational and thus should not persist, Briggs responds, "Experience, however, has demonstrated that it cannot be realistically assumed that labor markets function solely on the basis of merit and productivity." Instead, he argues, "It has been revealed that the roots of discrimination run deep into the institutional practices that prepare workers to compete in the labor market" (Briggs 1987b, p. 1231).

In Briggs's view, equal employment opportunity must begin by requiring antidiscrimination mechanisms that not only monitor hiring practices and patterns but also offer redress in the event of discriminatory actions. As he wrote in 1987 , for some women and minorities, it is enough to ask for hiring requirements to be job related and for employment practices to be fair. This alone can sometimes "open up employment opportunities where they previously did not exist" (Briggs 1987b, pp. 1231 and 1234).

Other times, however, biases and discrimination go much deeper and help explain why certain groups within the labor force might not appear in the applicant pool of a fair-minded 
employer. For example, recruitment and job-posting practices can be structured (even inadvertently) in a way that favors some groups over others. In addition, inequality and discrimination can shape the institutions that educate, train, and prepare people for employment, and past patterns of discrimination can cause even those with educational or training opportunities to temper their occupational aspirations and forego such opportunities out of discouragement. Thus, Briggs has always believed that active outreach, training, apprenticeship, and placement programs are indispensable tools in the pursuit of equal employment opportunity (Briggs 1987b, pp. 1231-1234) ${ }^{18}$

\section{Personal Development and International Well-being}

Briggs's final two HRD dimensions look beyond the national economy and focus on personal development and international well-being. As mentioned at the outset of this chapter, Briggs believes human resources are the key to personal development as well as to a healthy national economy. Thus, it is not surprising that part of the benefit accruing to an individual from HRD is economic and comes from opportunities associated with being adequately prepared for employment (Briggs 1987b, p. 1235). At the same time, another part of the individual benefit of developing one's human resources is that it provides the chance to be a more informed member of society—in Briggs's words, HRD heightens "one's broader awareness of the quality of the society of which he or she is a part" (Briggs 1987b, p. 1235).

Of course, economists have long recognized there are social as well as individual implications of an investment in human resources (indeed, education offers the classic case of a good with a positive externality), and Briggs believes the civic benefits of an educated and informed citizenry can be as potent as the economic ones. He surveys the awesome ability of science and technology to create, destroy, and "reshape the relationship of human beings to their 
natural environment," and he writes, "It is imperative that the uses of these forces be the result of the decisions made by an informed citizenry and not by an opinionated or indifferent society" (Briggs 1987b, p. 1235).

That last point connects the personal to the political, but it also connects the individual to the rest of humanity. Much of Briggs's work has focused on well-being at the national level, but he has always viewed a prosperous and humane U.S. economy as providing us with the best position from which to address problems on an international scale. Moreover, over the years he has given increasing attention to international issues. Not surprisingly, his message centers on leveling the playing field in a way that brings up those at the bottom, rather than encouraging a global race to the bottom.

I recall finding evidence of this in his remarks delivered as part of the ILR School's fortieth anniversary celebration. Toward the end of his talk on government regulation, Briggs noted: "In the 1980 s, we have seen the coming of the internationalization of our economy. This raises a whole new series of concerns about regulation... The next step will be the need to establish international labor standards. It is a difficult task, but I do think it is possible" (Briggs 1987a, p. 7).

Briggs returned to this theme more recently in an e-mail message. Responding to the draft of an article I composed for the sixtieth anniversary of the Labor and Employment Relations Association, he wrote: "In the conclusion, you might consider adding something to the effect that the reality in this present era of globalization is that many of the identical issues that confronted the founders of our organization and resulted in their focus on the national economy of the United States are rapidly becoming international issues. Whereas our organization helped 
set the buoys for intellectual inquiry [that involved] national studies, the challenge now is to try to do the same at the international level" (Briggs 2007).

\section{HUMAN RESOURCES: THE WEALTH OF NATIONS}

Briggs's quantitative, qualitative, and opportunity dimensions of HRD have always focused on national economic well-being. His personal development and international dimensions, however, address broader themes of individual fulfillment, civic virtue, and global responsibility. Reflecting on all of this, it is easy to see what I have found so compelling about Briggs's brand of economics. It is fitting, of course, to give him the last word, and what better way to do so than with a quote that ties together each of these dimensions and themes? "If human resources are truly 'the wealth of nations,' their development carries with it the parallel responsibility to recognize that their contribution to the economy must enhance the quality of life on this planet and not lead to its enslavement, impoverishment, or extinction" (Briggs 1987b, p. 1236)

\section{Notes}

1. Rather than rely on my course notes as a definitive source, I have tried to use them (and the course syllabus) primarily as a "road map" to further reading on the origin and development of HRE.

2. The book by Harbison and Myers is a direct precursor to the 1973 Harbison volume. Still, Eli Ginzberg, an early pioneer in HRE, stressed the importance of human resources to the wealth of a nation in an even earlier volume (Ginzberg 1958).

3. In the final edition of the Marshall and Briggs textbook, Labor Economics, they explain that the term "manpower policy" came into being in the 1960 s "to define the new set of labor market policies designed to develop the employment potential of the nation's human resources ... The 
European nations referred to these endeavors as 'active labor-market policies.' By the [late] 1970s, the term manpower itself had been replaced (it was felt to be a sexist term) by employment and training policies or human resource policies" (Marshall and Briggs 1989, p. $588)$

4. The second edition of Human Resources and Labor Markets: Labor and Manpower in the American Economy (1976) was one of two books listed as "general background references" in Briggs's 1980 course syllabus (the other was CETA Decentralization on Trial by Bonnie B. Snedeker and David M. Snedeker 1978) (Briggs 1980).

5. According to Briggs, CETA's public-service employment programs "were essentially counterstructural," not countercyclical, from 1978 to 1981, when funding was eliminated in the first year of the presidential administration of Ronald Reagan (Briggs 1982, p. 260).

6. The suggestion of shifting the Phillips Curve through human resource policies was also put forth in the early 1970s by Levitan, Mangum, and Marshall (1972, pp. 514-515). In addition, see Marshall and Briggs (1989, p. 594)

7. Indeed, Levitan, Mangum, and Marshall (1972, p. 515) called cyclical unemployment "demand-deficient unemployment."

8. To be sure, discussions of structural unemployment and its remedies are not absent from the pre-World War II economics literature; see, for example, Watkins (1922, pp. 222 and 234).

9. For a discussion of structural unemployment in the context of HRE, see also Levitan, Mangum, and Marshall (1972, pp. 515-517). For early discussions of structural unemployment, see Killingsworth (1965a,b); for a later reexamination, see Killingsworth (1979).

10. In the wake of the early 1960 s debate between structuralists and advocates of an aggregatedemand stimulus in the form of tax cuts, Congress passed the Economic Opportunity Act (EOA) 
of 1964 in addition to tax cuts. The EOA included "a number of experimental human resource programs" (Marshall and Briggs 1989, p. 595). Other programs with structural components would follow, including CETA.

10a. For my own analysis of recent U.S. economic performance from a perspective emphasizing economic change and focusing on implications for working families, see Whalen (2009).

11. Reflecting on the civil rights era from the vantage point of the mid 1980s, Briggs wrote: "There had to be changes in the racial and gender composition of employment patterns, as opposed to an exclusive policy focus merely on the level of employment. As a black leader once expressed it, "After all, we had full employment back on the plantations." At the same time, an equal-employment opportunity strategy must be accompanied by a full-employment strategy or the former will only heighten job-security concerns among groups that previously benefited from exclusionary employment practices (Briggs 1987b, pp. 1233-1234).

12. Myrdal's book also stresses that real-world problems often cut across the boundaries of academic disciplines: "In reality, there are not economic, sociological, or psychological problems, but simply problems, and ... as a rule they are all complex" (Myrdal 1969, p. 10). Still another point offered in the same section of Briggs's course is Robert A. Gordon's call for economic scholarship that has "“[real-world] relevance with as much rigor as possible' and not "rigor regardless of relevance" (quoted in Dunlop 1977, p. 282). Briggs, of course, accepts both of these points.

13. Even when defending regulation regardless of the extent to which it causes a market to deviate from the perfectly competitive model, Briggs still stressed the possibility that workplace efficiency and equity may be compatible objectives: "In many ways, the coming of regulation ... has probably led to more efficient labor markets in the process, because they are now more 
equitable ... Companies which have strong social consciences should not be forced to compete with those that have the least social conscience" (Briggs 1987a, p. 7). Briggs also recognized there are limits to government's ability to regulate effectively. His solution was squarely in the John R. Commons tradition: "What needs to be done in the health and safety area, for example, is to establish health and safety committees in the workplace and empower these committees to close down or stop production if they think there are violations. At the enterprise level, they know better than some inspectors if there is some danger or violation" (Briggs 1987a, p. 8). 14. Other marginally attached workers indicate they have not recently looked for work due to reasons such as family responsibilities and school attendance (U.S. BLS 2009). 15. For evidence that supports Briggs's concern about the harmful impact of immigrants upon low-skill U.S. labor markets, see Sum et al. (2004a).

16. For more on Briggs's view on immigration policy, see Chapter 2 by William P. Curington (which is based on Curington 2007). See also Briggs (1996, especially p. 381), which indicates a wariness regarding short-term immigration measures designed to relieve shortages (because such measures may cause us to "miss the opportunity to draw additional U.S. workers into the economic mainstream").

17. On linking education and training with industrial policy, Briggs writes: "There can be little purposeful long-term educational preparation of the labor force for employment if there is little direction provided as to where the economy is thought to be going" (Briggs 1987b, p. 1231). 18. Writing in 1987 , Briggs argued that antidiscrimination policies must continue because "it is unlikely that the principles of equal employment opportunity have yet been fully institutionalized to the degree that they can be taken for granted" (Briggs 1987b, p. 1234). Even with the passage of more than 20 years and the recent election of an African-American president, I suspect Briggs 
continues to hold the same view today. Indeed, in Chapter 9, Seth D. Harris provides evidence that would support Briggs in this stance. 


\section{References}

Briggs, Vernon M. 1980. "Public Policy and the Development of Human Resources." Cornell ILR 261. Course Syllabus and class notes as transcribed by the author (Whalen) 1982. "The Revival of Job Creation Programs in the 1970s: Lessons for the 1980s." In Proceedings of the Thirty-Fourth Annual Meeting, Barbara D. Dennis, ed. Madison, Wisconsin: Industrial Relations Research Association, pp. 258-265. . 1987a. "The Role of Government in the Workplace." ILR Report 24(2): 7-8. 1987b. "Human Resource Development and the Formulation of National Economic Policy." Journal of Economic Issues 21(3): 1207-1240. 1989. "Efficiency and Equity as Goals for Contemporary U.S. Immigration Policy." Center for Advanced Human Resource Studies working paper no. 89-02. Ithaca, New York: School of Industrial and Labor Relations, Cornell University. . 1996. "Immigration Policy and the U.S. Economy: An Institutionalist Perspective." Journal of Economic Issues 30(2): 371-387. 2003. Mass Immigration and the National Interest: Policy Directions for the New Century, third edition. Armonk, New York: M.E. Sharpe 2007. E-mail message to the author. August 27.

Commons, John R. and John B. Andrews. 1916. Principles of Labor Legislation. New York: Harper and Brothers.

Cornell University. 2009. "Vernon Briggs: Biography." Cornell University ILR School. $<$ http $/ /$ www.ilr cornell.edu/directory/vmb2/biography.htm $>$ (accessed February 13, 2009) 
Curington, William P. 2007. Interview with Vernon M. Briggs Jr. Copy deposited in the Kheel Center for Labor-Management Documentation and Archives, Martin P. Catherwood Library, School of Industrial and Labor Relations, Cornell University, Ithaca, New York Dunlop, John T. 1977. "Policy Decisions and Research in Economics and Industrial Relations." Industrial and Labor Relations Review30(3): 275-282.

Ginzberg, Eli. 1958. Human Resources: The Wealth of a Nation. New York: Simon and Schuster.

Gosling, James J. 2008. Economics, Politics, and American Public Policy. Armonk, New York: M.E. Sharpe

Harbison, Frederick H. 1973. Human Resources as the Wealth of Nations. New York: Oxford University Press.

Harbison, Frederick H. and Charles A. Myers. 1964. Education, Manpower, and Economic Growth: Strategies of Human Resource Development. New York: McGraw-Hill.

Heilbroner, Robert. 1986. The Worldly Philosophers: The Lives, Times and Ideas of the Great Economic Thinkers. New York: Simon and Schuster.

Hoefer, Michael, Nancy Rytina, and Bryan C. Baker. 2008. Estimates of the Unauthorized Immigrant Population Residing in the United States: January 2007. Washington, DC: Office of Immigration Statistics, U.S. Department of Homeland Security. Killingsworth, Charles. C. 1965a. "Automation, Jobs, and Manpower: The Case for Structural Unemployment." In The Manpower Revolution: Its Policy Consequences, Garth L. Mangum, ed. Garden City, New York: Anchor Books, pp. 97-117. 
1965b. "Unemployment After the Tax Cut." In Unemployment in a Prosperous Economy, William G. Bowen and Frederick H. Harbison, eds. Princeton, New Jersey: Industrial Relations Section, Princeton University, pp. 82-97. . 1979. "The Fall and Rise of Structural Unemployment." Proceedings of the Thirty-First Annual Meeting, Barbara D. Dennis, ed. Madison, Wisconsin: Industrial Relations Research Association, pp. 1-13.

Kirsch, Irwin S., Ann Jungeblut, Lynn Jenkins and Andrew Kolstad. 2002. Adult Literacy in America: A First Look at the Findings of the National Adult Literacy Survey, third edition. NCES 1993-275. Washington, DC: National Center for Education Statistics, Office of Educational Research and Improvement, U.S. Department of Education.

Kuttner, Robert. 1984. The Economic Illusion: False Choices Between Prosperity and Social Justice. Boston: Houghton Mifflin.

Levitan, Sar A., Garth L. Mangum, and Ray Marshall. 1972. Human Resources and Labor Markets: Labor and Manpower in the American Economy. New York: Harper and Row. Mangum, Garth L. 1976. Employability, Employment, and Income: A Reassessment of Manpower Policy. Salt Lake City: Olympus Publishing.

Marshall, Ray and Vernon M. Briggs. 1989. Labor Economics: Theory, Institutions, and Public Policy, sixth edition. Homewood, Illinois: Irwin.

Mincy, Ronald B, ed. 2006. Black Males Left Behind. Washington, DC: Urban Institute Press. Morry, Chris. 2003. "Illiteracy in the United States." The Communication Initiative Network (Summary of Findings of the Words are Your Wheels Literacy Program). $<$ http $/ /$ www.comminit.com/en/node/17040> (accessed February 13, 2009) 
Myrdal, Gunnar. 1969. Objectivity in Social Research. Middletown, Connecticut: Wesleyan University Press.

Piore, Michael J. 1974. "The Importance of Human Capital Theory to Labor Economics: A Dissenting View." In Proceedings of the Twenty-Sixth Annual Winter Meeting, Barbara D. Dennis, ed. Madison, Wisconsin: Industrial Relations Research Association, pp. 251258.

Rohe, John F. 2006. "Living Standards, Scarce Resources and Immigration: An Interview with Labor Economist Vernon M. Briggs Jr." The Social Contract 16(4): 227-236.

Schultz, Theodore W. 1961. "Investment in Human Capital." The American Economic Review 50(1): $1-17$.

Smith, Adam. 1935. An Inquiry into the Nature and Causes of the Wealth of Nations. New York: The Modern Library. Originally published in 1776.

Snedeker, Bonnie B. and David M. Snedeker. 1978. CETA. Decentralization on Trial. Salt Lake City: Olympus Publishing.

Sum, Andrew, Neeta Fogg, Ishwar Khatiwada, and Sheila Palma. 2004a. "Foreign Immigration and the Labor Force of the United States: The Contributions of New Foreign Immigration to the Growth of the Nation's Labor Force and Its Employed Population, 2000 to 2004." Boston: Center for Labor Market Studies, Northeastern University.

Sum, Andrew, Iswar Khatiwada, Frimpomaa Ampaw, Paulo Tobar, and Sheila Palma. 2004b "Trends in Black Male Joblessness and Year-Round Idleness: An Employment Crisis Ignored." Prepared for Alternative Schools Network, Chicago, Illinois. Available at $<$ http://www.nlc.org $>$ (accessed February 13, 2009). 
U.S. Bureau of Labor Statistics. 2008. "Marginally Attached Workers (Current Population Survey)." Defined in BLS Information Glossary. <http $/ /$ www.bls.gov/bls/glossary.htm> (accessed February 13, 2009) . 2009. "The Employment Situation: January 2009." Washington, DC: U.S. Department of

Labor. <http:/www.bls.gov/news.release/empsit.nr0.htm> (accessed February 13, 2009). Watkins, Gordon S. 1922. An Introduction to the Study of Labor Problems. New York: Thomas Y. Crowell Company.

Whalen, Charles J. 2009. "An Institutionalist Perspective on the Global Financial Crisis." Cornell University, School of Industrial and Labor Relations working paper, http://digitalcommons.ilr.cornell edu/intlvf/27. 